\title{
THE POSSIBILITY OF USING THE GEOGRAPHICAL. INFORMATION SISTEMS IN THE PIPE TRANSPORT OF THE ARMED FORCES OF SLOVAKIA
}

The paper describes possibilities of the geographical information systems' usage in the pipe transport. All parts of information systems including hardware, software, peopleware, dataware and orgware are in a continuous process of development. Advantages and disadvantages of GISs are their important part. Pipe transport is part of transport provision in Slovakia. The Armed Forces of the Slovak Republic are preparing universal units for usage throughout the whole world. The pipe transport supported by a GIS is able to move different liquids into all crises places.

\section{Introduction}

Contemporary information systems oriented towards management support of all people's activities are based on databases systems and transformed to geographical systems. The Armed Forces of the Slovak Republic have planned creation of several information systems. One of them uses geographical systems for pipe transport.

\section{Possibility of geographical information} systems' creation

The Geographical Information System (GIS) is the most dynamically developing system from all existing information systems. It is because of the crucial role of object and phenomenon localization, which are processed by this system. There has been observed an increase of the usage of Geographical Information Systems in private and public sectors. Concerning development of GISs, there were various problems to deal with in the past. Hardware and software were too expensive, graphic data were expensive as well and it was difficult to get them. At the same time knowledge of the users of a GIS had to be above-standard. Nevertheless, rapid development of technologies has caused that GISs are becoming more acceptable.

There are various forms of GISs. These systems differ according to their time and financial demands. As to information systems, requirements of every organization differ. The reasons are various kinds of data processing, present condition and quality of used data, and different technological equipment.

One of the main objectives of transport logistics is development of such systems and subsystems, which would command and control transport logistics compatible with NATO countries.
Development of a modern GIS is a common objective of the Armed Forces of the Slovak Republic (AF SR) and NATO. This system should comply with the latest requirements for data-processing, as well as for transmission and interpretation of results. The start of GIS's operation is supported by development of software, hardware and the Internet.

Military transport authorities have always used communication systems. Military transport controllers are considered to be basic elements in data processing. Telephones, teleprinters and faxes are their main means of communication. Development of computer technology allows the use of personal computers for processing and transmission of information.

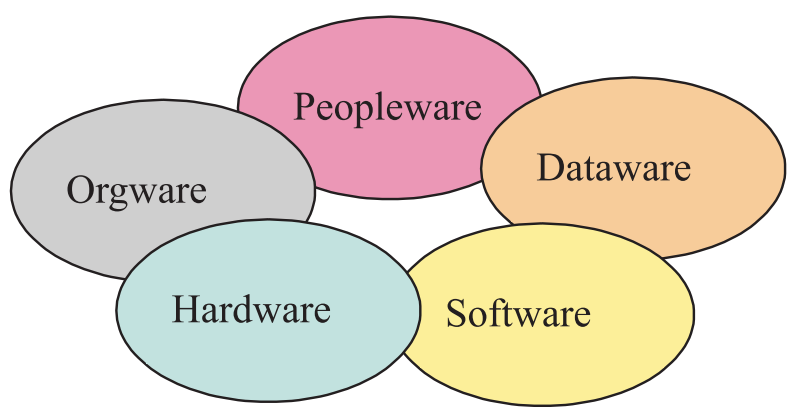

Fig. 1. Basic parts of an information system.

\subsection{Information system should comprise two levels}

1. Collection of information, development of information databases and processing of documents, necessary for the increase of managerial activities' effectiveness;

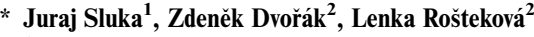

${ }^{1}$ Armed Forces of the Slovak Republic, Zemianské Kostolany, E-mail: Sluka@pobox.sk

${ }^{2}$ Department of Technical Sciences and Informatics, Faculty of Special Engineering, University of Žilina, E-mail: Zdenek.Dvorak@fsi.utc.sk,

Lenka.Rostekova@fsi.utc.sk, phone: ++421 41513 6854, 5136859
} 
2. Process of collection and activation of information and information documents necessary for performance of information services (automatic information forwarding to users).

All geographical information systems of the military transport should be divided and linked vertically and horizontally. Vertically in the system of providing defense of the Slovak Republic starting from Security Council of Slovakia, through territorial authorities of the military transport, to the executive authorities of military transport. At a horizontal level linking with military authorities within the framework of territory, public administration authorities, authorities of the Railways of the Slovak Republic, and transport companies is necessary.

\subsection{Advantages of GIS application in military transport:}

- digital principle of activity,

- transfer of real-time information,

- high degree of safety of transferred information,

- high quality of processed data,

- compatibility of individual subsystems (mutual and with NATO countries),

- increase of speed and quality of monitoring,

- increase of speed and quality of operative control,

- decrease of human failure coefficient,

- availability and variety of real-time information,

- possibility of database upgrading,

- low operating costs (capacity/effectiveness ratio).

\subsection{Disadvantages of GIS:}

- high expenses for development of the system,

- lack of experts in the Armed Forces of the Slovak Republic,

- lack of software and hardware equipment in the Armed Forces of the Slovak Republic,

- high requirements for the level of protection of technical equipment, program equipment and data structure of an information system.

\section{Basic parts of a GIS in military transport}

\subsection{Preparation and creation of a project for concrete application}

According to tasks and aims, which a GIS has to solve, there are specified individual points of a project:

- requirements of clients,

- costs,

- GIS safety level,

- data preparation, processing and transfer rate,

- operating costs (software, hardware...),

- analyses and interpretation of results,

- outputs (graphic description),

- usage of original subsystems (to minimize expenses)

\subsection{Databases}

Data processing by individual authorities of the military transport has existed since the computers started to be used. Differences between the inner structure of data cause that we cannot use the same databases in various thematic models of a GIS. Their usage depends either on partial adjustments, or on new databases structures' development.

In the conditions of military transport we can use these already existing databases:

- databases of infrastructure (technical parameters of selected road and railway networks, parameters of pipelines ...),

- databases of technical means and means of transport (capacity, fuel consumption, tactical-technical data ...).

The usage of individual databases depends on a concrete GIS and on the inner structure of data.

\subsection{Software systems}

The choice of software depends on requirements of a user (a client). Nowadays we have a sufficient amount of various GISs. Everything depends on hardware capacity, speed of data preparation, data-processing and on the speed of data transfer. The choice of a system is also influenced by an output device in the area of military transport. The choice of an information system is influenced mainly by the kind of transport.

\subsection{Analysis and interpretation of graphic information selection}

Graphic information can include:

- Automobile transport (effective usage of vehicles, their consumption, statistics of route's length, monitoring of vehicles' movement in a real time, choice of the shortest route ...),

- Railway transport (real time train set movement monitoring, real time shipping capacity, usage of carriages, consumption of electric energy or other kinds of fuel),

- Pipe transport (monitoring of transported product's leakage, amount of transported products, and capacity of pumping equipment ...),

- Air transport (statistics of hours flown, fuel consumption, real time airplane movement monitoring ...).

\subsection{Outputs}

A choice of outputs is offered during the work with a GIS. The outputs depend on specific requirements of their user, his economic potential and actual usage of a GIS (in terrain, in transport means), stationary equipment, and selected level of security.

Final outputs will use maximum number of the best quality data in minimum time. This is restricted by technical and software parameters of a specific GIS. 


\section{Position and importance of pipe transport in the Armed Forces of the Slovak Republic}

Pipe transport has been mostly used as a technological transport. It has gradually developed and formed its characteristic features.

Pipe transport is used mainly for:

- long distance transport of fuel, usually between state pipelines and warehouses,

- building of pipelines in the area of damaged railway lines,

- ground or air forces supply.

Fuel pipe transport units can be used in the state of crisis in the Slovak Republic or abroad, within the framework of UN units, in these cases:

- fulfillment of transport tasks within the framework of UN units,

- minimization of accident consequences,

- assistance in reconstruction and modernization of present elements of infrastructure,

- evacuation of oil stock in case of an ecological disaster,

- transport of huge volume of water to extinguish a fire or to provide water regime in areas, which suffer of extreme drought,

- drawing off of huge volumes of water from important flooded objects.

In the past managerial activities of the pipe transport resulted mainly from previous practices based on headquarters' experience, as well as on maps, graphical and textual enclosures. Nowadays there is a possibility to prepare a functioning GIS, which should contain:

- provision of a continuous preparation of units and material for the fulfillment of tasks connected with building, operation and rolling up of field pipelines (FP),

- tasks setting for units, which build, operate and roll up FP,

- organization of cooperation,

- uninterrupted connection with units, operating and technical elements of FP,

- maneuvers with forces, technical means and material,

- control of units which build, operate and roll up PDP,

- organization of accidents and problems' removal on PDP,

- protection and defense of an organization.

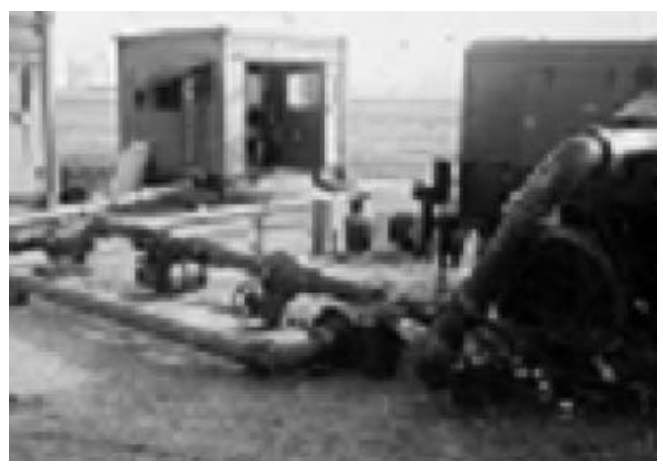

Fig. 2. Military pipeline equipment.
These are general stages of managerial activities in pipe transport:

1. Planning

2. Building of PDP

3. Operating of PDP

4. Rolling up PDP

\section{Possibilities of a GIS usage in the pipe transport within the framework of the Armed Forces of the Slovak Republic}

GIS usage in the pipe transport seems to be an advantageous way to improve transport and supply systems in the Armed Forces of the Slovak Republic. The civil sector uses a GIS for a pipeline operation in the Slovak Republic. Because activities of the pipe transport units are narrowly linked with pipelines' operation, there is a real possibility to use the civil sector GIS experience and to prepare a similar GIS for the usage within the framework of the Armed Forces of the Slovak Republic. An application of such a GIS in the Armed Forces of the Slovak Republic would be more difficult from the point of view of operation and reliability during the compulsory state alert. We should think about a kind of a Mobile GIS model. Its main task would be to offer responsible stereoscopic information in the right place, in actual time and using minimum costs.

\subsection{Advantages of a GIS's application in the pipe transport:}

- decrease of operating costs (lower costs for external services, higher effectiveness of maintenance),

- planning of costs for a specific combat mission,

- prevention of breakdowns (better prevention of breakdowns and better evaluation of pipelines' renewal),

- quick and latest information about pipeline technology and its surroundings in the case of a breakdown,

- analytical information (analyses of space, analyses of medium leakage into terrain ...),

- digital principle of its activities,

- transfer of information in actual time,

- high degree of safety of transferred information,

- high quality of processed data,

- mutual compatibility of individual subsystems, and their compatibility with NATO,

- increase of speed and quality of monitoring,

- increase of speed and quality of operative control,

- decrease of a human failure coefficient

- availability and variety of real-time information,

- possibility of database updating

- possibility for the usage of the pipe units abroad (usage of a digital model of a country)

\subsection{Disadvantages of a GIS in the pipe transport:}

- high expenses for the system's setting up, 
- lack of experts in the Armed Forces of the Slovak Republic,

- lack of software and hardware equipment in the Armed Forces of the Slovak Republic,

- high expenses for installation of pumping units monitoring equipment,

- high requirements for the level of protection of technical equipment, program equipment and information system data structure.

A high quality GIS preparation for pipeline units' activities makes managerial activities easier. It will provide the fulfillment of combat missions with NATO units, wherever all over the world.

Information systems are one of the basic problems solved within the framework of transformation of the Armed Forces of the
Slovak Republic. Proposed and prepared solutions put emphasis on a linkage of information systems with managerial activities connected with the State Information System. This brings improvement to managerial activities in all spheres.

\section{Conclusion}

An implementation of new and modern software in military corps is one of the main future tasks. Our managerial staff is very well prepared for all managerial activities. Currently, there is a great possibility to create new information systems based on Geographical Information Systems.

\section{References}

[1] DVOŘÁK, Z. et al.: Technology and Services of Intelligent Transport in Conditions of the Slovak Republic, ŽU v Žiline, 2005, pp. 83-97.

[2] SEIDL, M., TOMEK, M.: The Usage of Pipe Transport in Crises Situations, ŽU v Žiline, ISBN 80-8070-187-3, 2004, pp. 24 and 33

[3] SLUKA, J., DVOŘÁK, Z., KAŠPAR, V.: Geographical Information Systems and Pipe Transport, In: Sborník - Krizový management v dopravě a státní správě, 2003, Pec pod Snežkou, ISBN 80-86530-10-8

[4] ŠIMÁK, L. et al.: Transport in Crises Situations, ŽU v Žiline, 1999, ISBN 80-88829-53-4

[5] TOMEK, M., LUSKOVÁ, M.: Alternative Long Distance Pipeline and Crises Situations, In: Sborník 4. konference s mezinárodní účastí Krizové stavy a doprava. Pardubice, Institut Jana Pernera, 2004, p. 149-153, ISBN 80-86530-20-5 